\title{
SISTEM PENDUKUNG KEPUTUSAN SELEKSI PENERIMA PEGAWAI BERPRESTASI DENGAN MENGGUNAKAN SIMPLE ADDITIVE WEIGHTING (STUDI KASUS PADA KANTOR KECAMATAN KUNINGAN)
}

\author{
Dani Apriansyah \\ Program Studi Sistem Informasi, Fakultas Ilmu Komputer, Universitas Kuningan \\ e-Mail : apriansyah.dani44@gmail.com
}

\begin{abstract}
ABSTRAK
Kecamatan Kuningan merupakan salah satu instansi yang terdapat di Kabupaten Kuningan. Kecamatan Kuningan selalu melakukan pengusulan Pegawai Berprestasi kepada Pemerintah Daerah. Pengusulan Pegawai Berprestasi dilakukan setiap satu tahun sekali dengan cara memilih salah satu pegawai yang bersedia untuk diusulkan sebagai Pegawai Berprestasi. Seleksi dengan cara tersebut sering didapati Pegawai Berprestasi yang diusulkan kurang layak. Hal tersebut terjadi karena proses seleksi masih menggunakan satu kriteria (prakarsa), sehingga ketika beberapa pegawai yang ada memiliki nilai yang berbeda, maka sering didapati pengambilan keputusan yang subjektif dan tidak tepat sasaran. Sehubungan dengan permasalahan tersebut, maka dalam proses seleksi penerima pengusulan Pegawai Berprestasi digunakan kriteria lain seperti: kedisiplinan, kinerja dan pengabdian. Namun, dengan bertambahnya jumlah kriteria dalam proses seleksi mengakibatkan pemecahan masalah dari seleksi tersebut semakin kompleks. Alternatif solusi yang diusulkan yaitu membuat sistem pendukung keputusan menggunakan metode Simple Additive Weighting yang diharapkan dapat membantu pimpinan dalam pengambilan keputusan yang cepat, tepat sasaran dan objektif. Metode Simple Additive Weighting dipilih karena dapat membantu penyelesaian masalah pembuatan keputusan yang melibatkan banyak kriteria. Sistem tersebut dibangun dengan teknik pengembangan System Development Life Cycle model Waterfall dengan teknik pendekatan pengembangan sistem terstruktur menggunakan bahasa pemrograman PHP Hypertext Preprocessing dan DataBase Management System MySQL. Implementasi sistem tersebut menunjukan bahwa Sistem yang dibangun dapat mendukung pimpinan dalam pengambilan keputusan yang cepat, tepat sasaran dan objektif. Artinya, penerapan multi atribut (kriteria) dan Sistem Pendukung Keputusan menggunakan metode SAW pada proses pengambilan keputusan seleksi penerima Pegawai Berprestasi pada kantor Kecamatan Kuningan dapat mengurangi tingkat ketidaklayakan Pegawai yang diusulkan.
\end{abstract}

Kata Kunci: Sistem Pendukung Keputusan, Seleksi Pegawai Berprestasi, Multi-Attribute Decision Making, Simple Additive Weighting

\section{PENDAHULUAN}

Dewasa ini perkembangan sistem informasi semakin pesat, yang awalnya hanya mendukung transaksi hingga sekarang mendukung pekerjaan yang bersifat analitis. Perkembangan sistem informasi yang pesat tersebut mengakibatkan sistem informasi banyak digunakan di berbagai bidang pekerjaan, baik dalam organisasi maupun instansi.

Kecamatan Kuningan merupakan salah satu instansi yang terdapat di Kabupaten Kuningan. Dalam tujuan agar pegawai selalu memacu semangat dalam dirinya untuk terus meningkatkan atau bahkan mempertahankan dedikasi dan kinerjanya, maka Kecamatan Kuningan selalu melakukan pengusulan Pegawai Berprestasi kepada Pemerintah Daerah. Adapun, pengusulan Pegawai Berprestasi tersebut dilakukan setiap satu tahun sekali dengan cara memilih salah satu pegawai yang bersedia (prakarsa) untuk diusulkan sebagai Pegawai Berprestasi. Seleksi dengan cara tersebut sering didapati Pegawai Berprestasi yang diusulkan kurang layak. Hal tersebut 
terjadi karena proses seleksi hanya menggunakan satu kriteria (prakarsa) sehingga ketika beberapa pegawai yang ada memiliki nilai yang berbeda, maka sering didapati pengambilan keputusan yang subjektif dan tidak tepat sasaran.

Sehubungan dengan permasalahan tersebut, maka dalam proses seleksi penerima pengusulan Pegawai Berprestasi diperlukan kriteria-kriteria lain yang dapat dijadikan acuan agar pengambilan keputusan dapat tepat sasaran dan objektif. Di sisi lain, dengan bertambahnya jumlah kriteria dalam proses seleksi tersebut mengakibatkan pemecahan masalah dari seleksi tersebut semakin kompleks. Sehingga, untuk memecahkan permasalahan tersebut diperlukan analitis terkomputerisasi, agar dihasilkan pengambilan keputusan yang cepat, tepat sasaran dan objektif.

Salah satu solusi untuk permasalahan tersebut adalah dengan penerapan sistem pendukung keputusan dengan metode Simple Additive Weighting (SAW). Kusrini (2007: 15) berpendapat bahwa: Sistem pendukung keputusan merupakan sistem informasi interaktif yang menyediakan informasi, pemodelan dan pemanipulasian data. Sistem yang digunakan untuk membantu pengambilan keputusan dalam situasi yang semistruktur dan situasi yang tidak terstruktur. Dan SAW merupakan salah satu model yang dapat digunakan untuk pembuatan keputusan yang melibatkan banyak kriteria (Multi Attribute Decision Making).

Diharapkan dengan penerapan solusi tersebut keputusan yang diambil merupakan keputusan yang tepat sasaran dan objektif. Selain itu, dengan penerapan sistem yang terkomputerisasi diharapkan dapat mempersingkat waktu proses pengambilan keputusan.

\section{LANDASAN TEORI \\ Pegawai Berprestasi}

Pegawai Berprestasi adalah sebuah penghargaan yang diberikan kepada Pegawai Negeri Sipil yang memiliki hasil kerja yang berkualitas dan terukur dalam melaksanakan tugas pokok dan fungsi sesuai dengan jabatan yang diemban dan diakui di Pemerintahan Daerah.

\section{Persyaratan Pegawai Berprestasi}

Persyaratan pemberian Pegawai Berprestasi sebagaimana tercantum dalam Peraturan Bupati Kuningan Nomor 36 Tahun 2015 tentang Pemberian Penghargaan Kepada Pegawai Negeri Sipil Berprestasi adalah sebagai berikut:

1. Kategori

Pemilihan Pegawai Berprestasi dibagi menjadi empat kategori, yaitu sebagai berikut:

a. Pegawai yang menduduki Jabatan Struktur Eselon III

b. Pegawai yang menduduki Jabatan Struktur Eselon IV.

c. Pegawai yang menduduki Jabatan Fungsional Tertentu/Angka Kredit.

d. Pegawai yang menduduki Jabatan Fungsional Umum/Pelaksana.

2. Persyaratan Umum

Persyaratan umum pemberian Pegawai Berprestasi adalah sebagai berikut:

a. Pegawai Negeri Sipil di Lingkungan Pemerintah Kabupaten Kuningan.

b. Sehat jasmani dan rohani.

c. Tidak pernah dijatuhi hukuman disiplin dan hukuman pidana kururngan atau penajara selama dua tahun terakhir.

d. Memiliki masa pengabdian di lingkungan Pemerintah Kabupaten Kuningan minimal lima tahun sejak diangkat sebagai Pegawai Negeri Sipil secara terus menerus tanpa terputus.

e. Setiap unsur Penilaian Prestasi Kerja Pegawai Negeri Sipil bernilai baik dalam dua tahun terakhir.

f. Tingkat kehadiran atau absensi sekurang-kurangnya 90\% dalam satu tahun terkahir.

g. Belum pernah mendapatkan penghargaan Pegawai Negeri Sipil Berprestasi dalam tiga tahun terkahir.

3. Persyaratan Khusus

a. Memiliki dedikasi dan prestasi dalam melaksanakan tugas. 
b. Bagi peserta yang lulus Tes Kemampuan Dasar (TKD) dan Psikotes membuat makalah mengenai inovasi berkaitan dengan substansi tugas pokok dan fungsi organisasi tempat tugas pegawai yang bersangkutan serta mempresentasikannya dihadapan Tim Penilai.

\section{Simple Additive Weighting (SAW)}

Kusumadewi (2006: 74) mengemukakan bahwa: "Metode SAW sering juga dikenal istilah metode penjumlahan terbobot. Konsep dasar metode SAW adalah mencari penjumlahan terbobot dari rating kinerja pada setiap alternatif pada semua atribut. Metode $S A W$ membutuhkan proses normalisasi matriks keputusan (X) ke suatu skala yang dapat diperbandingkan dengan semua rating alternatif yang ada."

\section{METODE}

\section{Metode Pengumpulan Data}

Metode pengumpulan data yang digunakan untuk mendapatkan data-data penelitian, yaitu sebagaimana berikut:

1. Penelitian Lapangan (Field Research)

Metode penelitian lapangan yang digunakan, yaitu wawancara. Responden dalam wawancara ini adalah KASUBAG Umum Kecamatan Kuningan.

2. Penelitian Kepustakaan (Library Research) Penelitian ini dilakukan dengan mengadakan penelaahan terhadap bukubuku litelatur, e-jurnal, media informasi dan peraturan-peraturan yang terkait.

\section{Metode Pengembangan Sistem}

Dalam pengembangan sistem ini digunakan System Development Life Cycle (SDLC) model waterfall dengan menggunakan teknik pendekatan pengembangan sistem terstruktur, sehingga tahapan-tahapan dalam pengembangan sistem ini adalah sebagaimana berikut:
1. Requirement Analysis and Definition

Pada tahap ini digunakan metode pengumpulan data, yaitu wawancara. Responden dalam pengembangan sistem ini adalah Camat dan KASUBAG Umum Kecamatan Kuningan. Berikut ini difenisikan hasil analisis:

\section{Analisis Kelemahan Sistem}

Berikut ini penulis definisikan analisis sistem berjalan pengambilan keputusan Seleksi Penerima Pegawai Berprestasi pada Kecamatan Kuningan, sebagaimana terlihat pada Gambar 1.

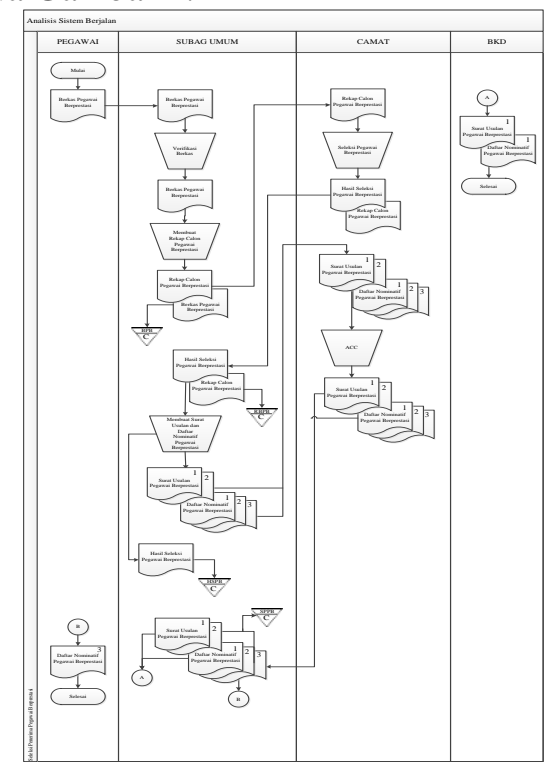

Gambar 1 Analisis Sistem Berjalan

Seleksi Penerima Pegawai Berprestasi

Berdasarkan Analisis Sistem Berjalan Seleksi Pegawai Berprestasi pada Kecamatan Kuningan dalam Gambar 1 dapat diidentifikasi kelemahan yang ada pada sistem yang berjalan adalah sebagaimana berikut:

1. Pengambilan keputusan masih bersifat subjektif dan tidak tepat sasaran dikarenakan hanya menggunakan satu kriteria, yaitu prakarsa. Sehingga, pegawai yang diusulkan sering kurang layak.

2. Belum adanya sistem terkomputerisasi dalam Seleksi Penerima Pegawai Berprestasi pada Kecamatan 
Kuningan, sehingga diperlukan sumber daya (waktu) lebih jika pengambilan keputusan menggunakan banyak kriteria.

Sehingga diusulkan sistem usulan sebagai solusi dari permasalahan pada sistem yang berjalan, sebagaimana terlihat pada Gambar 2.

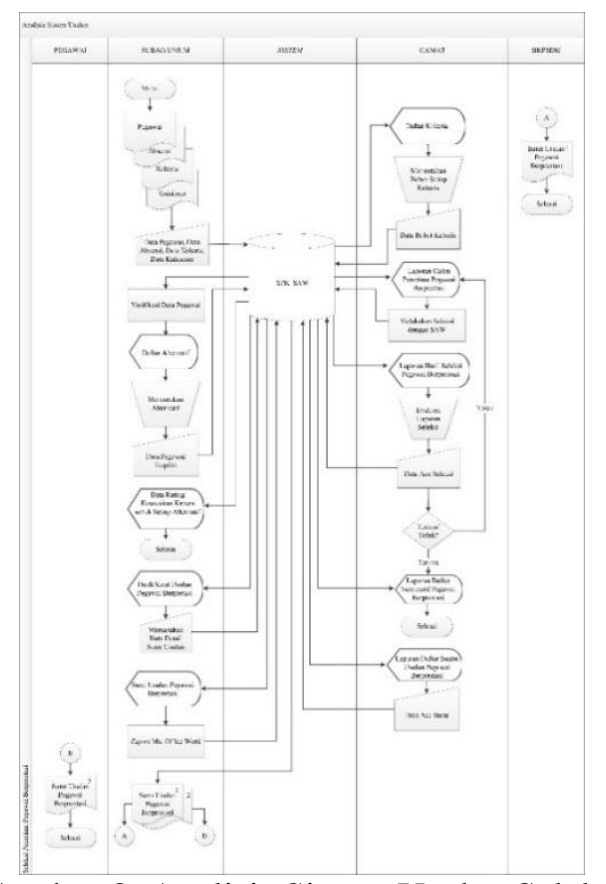

Gambar 2 Analisis Sistem Usulan Seleksi Pegawai Berprestasi

2. System and Software Design

Berikut ini penulis definisikan System and Software Design dalam pengembangan sistem ini:

\section{Diagram Konteks}

Berikut ini penulis definisikan diagram konteks dari Sistem Pendukung Keputusan Seleksi Penerima Pegawai Berprestasi dengan Menggunakan Metode SAW, sebagaimana terlihat pada Gambar 3.

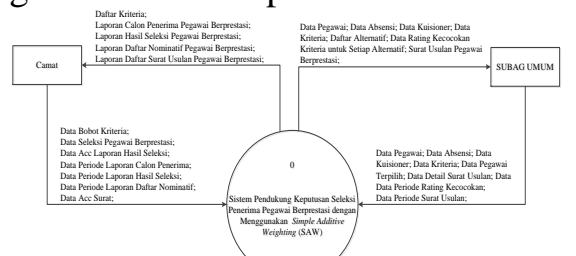

Gambar 3 Diagram Konteks Sistem Pendukung Keputusan Seleksi Penerima Pegawai Berprestasi

\section{DFD Level 0}

Berikut ini penulis definisikan DFD Level 0 dari Sistem Pendukung Keputusan Seleksi Penerima Pegawai Berprestasi Menggunakan Metode SAW, sebagaimana terlihat pada Gambar 4.

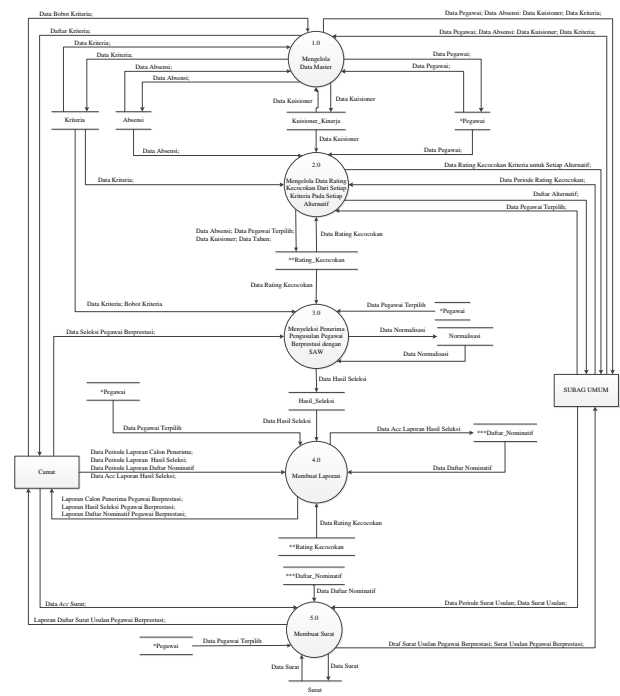

Gambar 4 DFD Level 0

\section{Model Relasional}

Berikut ini penulis definisikan desain basis data logis (model relasional) dari Sistem Pendukung Keputusan Seleksi Penerima Pegawai Berprestasi Menggunakan Metode SAW, sebagaimana terlihat pada Gambar 5.

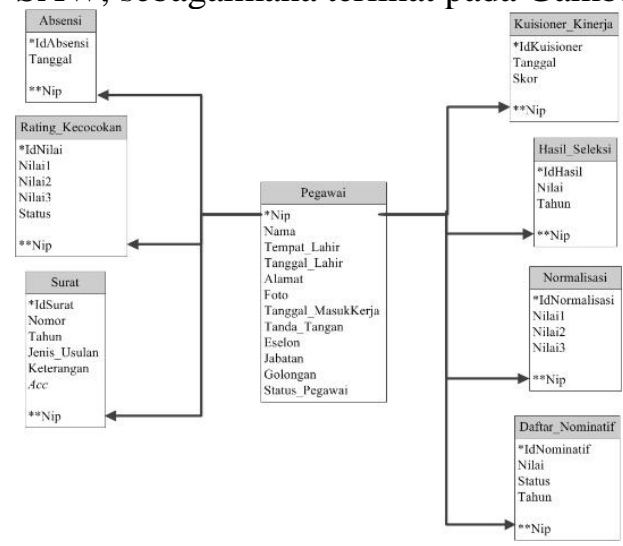

Gambar 5 Model Relasional

\section{Metode Penyelesaian Masalah}

Metode penyelesaian masalah yang digunakan dalam penelitian ini adalah Simple Additive Weighting (SAW). Sehingga, langkah-langkah dalam penyelesaian 
masalah ini adalah sebagaimana terlihat pada Gambar 6.

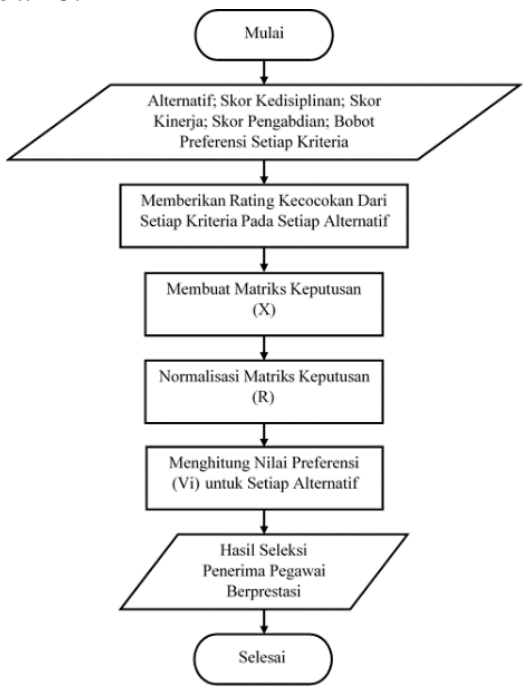

Gambar 6 Penyelesaian Permasalahan dengan Metode SAW

Berdasarkan Penyelesaian Permasalahan dalam Gambar 6, maka dapat didefinisikan tahapantahapan penyelesaian masalah Seleksi Pegawai Berprestasi menggunakan metode SAW adalah sebagaimana berikut:

a. Data Masukan

(1) Menentukan Alternatif

Alternatif adalah pegawai yang menjadi kandidat penerima Pegawai Berprestasi. Data pegawai yang digunakan sebagai alternatif pada sistem ini, sebagaimana terlihat pada Tabel 1.

Tabel 1 Daftar Alternatif

\begin{tabular}{|c|c|c|l|l|c|c||}
\hline NO. & NIP & Nama & $\begin{array}{l}\text { Tempat } \\
\text { Tanggal } \\
\text { Lahir }\end{array}$ & Jabatan & $\begin{array}{c}\text { Golongan } \\
/ \\
\text { Pangkat }\end{array}$ & Eselon \\
\hline 1 & 1960 & Drs. Sudiana & $\begin{array}{l}\text { Kuningan, 01- } \\
\text { 01-1960 }\end{array}$ & $\begin{array}{l}\text { Sekretaris } \\
\text { Kecamatan }\end{array}$ & III.D & III \\
\hline 2 & 1961 & Maryami, S.E & $\begin{array}{l}\text { Kuningan, 05- } \\
\text { 06-1961 }\end{array}$ & $\begin{array}{l}\text { KASUBAG } \\
\text { UMUM }\end{array}$ & III.C & IV \\
\hline 3 & 1962 & Indra, S.Sos & $\begin{array}{l}\text { Kuningan, 09- } \\
\text { 01-1962 }\end{array}$ & $\begin{array}{l}\text { Kasi } \\
\text { Pemerintahan }\end{array}$ & III.D & IV \\
\hline 4 & 1963 & Neni, S.E & $\begin{array}{l}\text { Kuningan, 01- } \\
\text { 07-1963 }\end{array}$ & Staf Pelaksana & III.B & Pelaksana \\
\hline 5 & 1964 & Agus, S.E & $\begin{array}{l}\text { Kuningan, 24- } \\
\text { 01-1964 }\end{array}$ & Staf Pelaksana & III.A & Pelaksana \\
\hline
\end{tabular}

(2) Menentukan Kriteria

Kriteria-kriteria yang digunakan dalam seleksi penerima Pegawai Berprestasi, yaitu sebagai berikut:

(a) Kedisiplinan

Kriteria kedisiplinan yang digunakan dalam seleksi penerima Pegawai Berprestasi diperoleh dari data absensi yang dikalkulasi berdasarkan periode (per tahun), sebagaimana terlihat pada Tabel 2.

Tabel 2 Data Kriteria Kedisiplinan

\begin{tabular}{|l|c|c|}
\multicolumn{1}{|c|}{ Nama } & $\begin{array}{c}\text { Skor } \\
\text { Kedisplinan }\end{array}$ & $\begin{array}{c}\text { Periode } \\
\text { Kedisiplinan }\end{array}$ \\
\hline Drs. Sudiana & 365 & 2017 \\
\hline Maryami, S.E & 365 & 2017 \\
\hline Indra, S.Sos & 360 & 2017 \\
\hline Neni, S.E & 350 & 2017 \\
\hline Agus, S.E & 340 & 2017 \\
\hline
\end{tabular}

(b) Kinerja

Kriteria kinerja yang digunakan dalam seleksi penerima Pegawai Berprestasi diperoleh dari data kuisioner kinerja yang dikalkulasi berdasarkan periode (per tahun), sebagaimana terlihat pada Tabel 3.

Tabel 3 Data Kriteria Kinerja

\begin{tabular}{|l|c|c|}
\hline \multicolumn{1}{|c|}{ Nama } & $\begin{array}{c}\text { Skor } \\
\text { Kinerja }\end{array}$ & Periode Kinerja \\
\hline Drs. Sudiana & 200 & 2017 \\
\hline Maryami, S.E & 600 & 2017 \\
\hline Indra, S.Sos & 300 & 2017 \\
\hline Neni, S.E & 500 & 2017 \\
\hline Agus, S.E & 400 & 2017 \\
\hline
\end{tabular}

(c) Pengabdian

Kriteria pengabdian yang digunakan dalam seleksi penerima Pegawai Berprestasi diperoleh dari data pegawai (masa kerja), sebagaimana terlihat pada Tabel 4.

Tabel 4 Data Kriteria Pengabdian

\begin{tabular}{|l|c|c|}
\hline \multicolumn{1}{|c|}{ Nama } & $\begin{array}{c}\text { Skor } \\
\text { Pengabdian }\end{array}$ & $\begin{array}{c}\text { Periode } \\
\text { Pengadian }\end{array}$ \\
\hline Drs. Sudiana & 15 & 2017 \\
\hline Maryami, S.E & 30 & 2017 \\
\hline Indra, S.Sos & 20 & 2017 \\
\hline Neni, S.E & 25 & 2017 \\
\hline Agus, S.E & 22 & 2017 \\
\hline
\end{tabular}


(3) Memberikan Bobot preferensi atau tingkat kepentingan (W) setiap kriteria Nilai bobot preferensi atau tingkat kepentingan (W) untuk masingmasing kriteria yang diberikan oleh Camat, sebagaimana terlihat pada Tabel 5.

Tabel 5 Bobot Preferensi (W) Setiap Kriteria

\begin{tabular}{|c|l|c|}
\hline Kode Kriteria & \multicolumn{1}{|c|}{ Nama } & Bobot \\
\hline C1 & Kedisiplinan & 5 \\
\hline C2 & Kinerja & 3 \\
\hline C3 & Pengabdian & 2 \\
\hline
\end{tabular}

b. Memberikan Rating Kecocokan dari Setiap Kriteria Pada Setiap Alternatif

Berdasarkan data masukan pada poin a kemudian dibuat rating kecocokan dari setiap kriteria pada setiap alternatif, sebagaimana terlihat pada Tabel 6.

Tabel 6 Rating Kecocokan dari Setiap

Kriteria Pada Setiap Alternatif

\begin{tabular}{|c|l|c|c|c|}
\hline \multirow{2}{*}{ NO } & \multirow{2}{*}{ Nama (Ai) } & \multicolumn{3}{|c|}{ Kriteria } \\
\cline { 3 - 5 } & & C1 & C2 & C3 \\
\hline 1 & Drs. Sudiana & 365 & 200 & 15 \\
\hline 2 & Maryami, S.E & 365 & 600 & 30 \\
\hline 3 & Indra, S.Sos & 360 & 300 & 20 \\
\hline 4 & Neni, S.E & 350 & 500 & 25 \\
\hline 5 & Agus, S.E & 340 & 400 & 22 \\
\hline
\end{tabular}

c. Membuat Matriks Keputusan (X)

Berikut ini adalah matriks keputusan (X) yang dibentuk berdasarkan rating kecocokan dari setiap kriteria pada setiap alternatif.

$$
X=\left[\begin{array}{lll}
365 & 200 & 15 \\
365 & 600 & 30 \\
360 & 300 & 20 \\
350 & 500 & 25 \\
340 & 400 & 22
\end{array}\right]
$$

d. Normalisasi Matriks Keputusan (R)

Pada normalisasi matriks digunakan persamaan sebagai berikut:

$r_{i j}=\frac{x_{i j}}{\operatorname{Max}_{i}} \quad, \quad$ jika j adalah atribut

keuntungan (benefit). $r_{i j}=\frac{\operatorname{Min}_{i j}}{X_{i j}}$, jika $\mathrm{j}$ adalah atribut biaya (cost).

Karena setiap nilai yang diberikan pada setiap alternatif di setiap kriteria merupakan nilai kecocokan (nilai terbesar adalah terbaik), maka semua kriteria yang diberikan diasumsikan sebagai kriteria keuntungan. Sehingga, persamaan yang digunakan untuk normalisasi matriks keputusan (X) adalah Persamaan (1). Berikut ini penulis definisikan perhitungan normalisasi matriks keputusan (X) pada seleksi penerima Pegawai Berpresasi berdasarkan Persamaan (1):

$\mathrm{r}_{11}=\frac{365}{\max \{365 ; 365 ; 360 ; 350 ; 340\}}=\frac{365}{365}=1$
$\mathrm{r}_{21}=\frac{365}{\max \{365 ; 365 ; 360 ; 350 ; 340\}}=\frac{365}{365}=1$
$\mathrm{r}_{31}=\frac{360}{\max \{365 ; 365 ; 360 ; 350 ; 340\}}=\frac{360}{365}=0.986$
$\mathrm{r}_{41}=\frac{350}{\max \{365 ; 365 ; 360 ; 350 ; 340\}}=\frac{350}{365}=0.958$
$\mathrm{r}_{51}=\frac{350}{\max \{365 ; 365 ; 360 ; 350 ; 340\}}=\frac{340}{365}=0.931$
$\mathrm{r}_{12}=\frac{200}{\max \{200 ; 600 ; 300 ; 500 ; 400\}}=\frac{200}{600}=0.333$
$\mathrm{r}_{22}=\frac{600}{\max \{200 ; 600 ; 300 ; 500 ; 400\}}=\frac{600}{600}=1$
$\mathrm{r}_{32}=\frac{300}{\max \{200 ; 600 ; 300 ; 500 ; 400\}}=\frac{300}{600}=0.5$
$\mathrm{r}_{42}=\frac{500}{\max \{200 ; 600 ; 300 ; 500 ; 400\}}=\frac{500}{600}=0.833$
$\mathrm{r}_{52}=\frac{400}{\max \{200 ; 600 ; 300 ; 500 ; 400\}}=\frac{400}{600}=0.666$
$\mathrm{r}_{13}=\frac{15}{\max \{15 ; 30 ; 20 ; 25 ; 22\}}=\frac{15}{30}=0.5$
$\mathrm{r}_{23}=\frac{30}{\max \{15 ; 30 ; 20 ; 25 ; 22\}}=\frac{20}{30}=1$
$\mathrm{r}_{33}=\frac{20}{\max \{15 ; 30 ; 20 ; 25 ; 22\}}=\frac{20}{30}=0.666$
$\mathrm{r}_{43}=\frac{25}{\max \{15 ; 30 ; 20 ; 25 ; 22\}}=\frac{25}{30}=0.833$
$\mathrm{r}_{53}=\frac{22}{\max \{15 ; 30 ; 20 ; 25 ; 22\}}=\frac{22}{30}=0.733$
$\mathrm{D}=1$

Dari perhitungan normalisasi matriks di atas, maka dihasilkan matriks ternormalisasi $\mathrm{R}$ sebagai berikut:

$$
\mathrm{R}=\left[\begin{array}{ccc}
1 & 0,333 & 0,5 \\
1 & 1 & 1 \\
0,986 & 0,5 & 0,666 \\
0,958 & 0,833 & 0,833 \\
0,931 & 0,666 & 0,733
\end{array}\right]
$$

e. Menghitung Nilai Preferensi Setiap Alternatif (Vi)

Setelah matriks ternormalisasi $\mathrm{R}$ diketahui, langkah selanjutnya adalah menghitung 
nilai preferensi setiap alternatif (Vi) dengan menggunakan Persamaan (3):

$$
V i=\sum_{j=1}^{n} w_{j} r_{i j}
$$

Proses perangkingan diperoleh berdasarkan

Persamaan (3) adalah sebagaimana berikut:

$\mathrm{V}_{1}=(5)(1)+(3)(0,333)+(2)(0,5)=6.999$

$\mathrm{V}_{2}=(5)(1)+(3)(1)+(2)(1)=10$

$\mathrm{V}_{3}=(5)(0,986)+(3)(0,5)+(2)(0,666)=7.762$

$\mathrm{V}_{4}=(5)(0,958)+(3)(0,833)+(2)(0,833)=8.955$

$\mathrm{V}_{5}=(5)(0,981)+(3)(0,666)+(2)(0,733)=8.369$

f. Hasil Seleksi

Proses perangkingan diperoleh berdasarkan

Persamaan (3) mendapatkan hasil seleksi, sebagaimana terlihat pada Tabel 7 .

Tabel 7 Laporan Hasil Seleksi Pegawai Berprestasi

\begin{tabular}{|c|l|c|c|c|c|c|}
\hline \multirow{2}{*}{ NO } & \multirow{2}{*}{ Nama (Ai) } & \multicolumn{3}{|c|}{ Kriteria } & \multirow{2}{*}{$\begin{array}{c}\text { Kategori } \\
\text { Jabatan }\end{array}$} & Hasil \\
\cline { 3 - 6 } & & Kedisiplinan & Kinerja & Pengabdian & \\
\hline 1 & Maryami, S.E & 365 & 600 & 30 & IV & 10 \\
\hline 2 & Neni, S.E & 350 & 500 & 25 & Pelaksana & 8.955 \\
\hline 3 & Agus, S.E & 340 & 400 & 22 & Pelaksana & 8.369 \\
\hline 4 & Indra, S.Sos & 360 & 300 & 20 & IV & 7.762 \\
\hline 5 & Drs. Sudiana & 365 & 200 & 15 & III & 6.999 \\
\hline
\end{tabular}

3. Implementation and Unit Testing

Sistem pendukung keputusan ini diimplementasikan dengan bahasa pemrograman PHP dan DBMS MySQL. Sedangkan, tool yang digunakan dalam melakukan pengujian unit adalah pengujian kotak putih (white-box testing).

4. Integration and System Testing

Pengujian sistem pada tahap ini menggunakan pengujian kotak hitam (blackbox testing).

5. Operation and Maintenance

\section{HASIL DAN PEMBAHASAN}

Pada uji coba sistem ini, untuk melakukan proses seleksi dengan metode SAW, maka harus dimasukkan data masukan. Uji coba dilakukan untuk mengetahui perbedaan hasil dari sistem berjalan dengan sistem usulan dan mengfungsionalitasi dari fitur yang ada pada sistem guna mengetahui kemampuan dan kelemahan sistem untuk digunakan pengembangan sistem lebih lanjut. Proses pengujian dilakukan berdasarkan data dari studi kasus untuk Seleksi Pegawai Berprestasi pada Kantor Kecamatan Kuningan. Hasil dari uji coba sistem tersebut, untuk maksud melakukan Seleksi Pegawai Berprestasi secara terkomputerisasi dengan bantuan SPK dan Metode SAW adalah sebagaimana berikut:

1. Antarmuka Data Pegawai

Antarmuka Data Pegawai pada Sistem ditampilkan seteleh proses login oleh user (Sub Bagian Umum), sebagaimana terlihat pada Gambar 7.

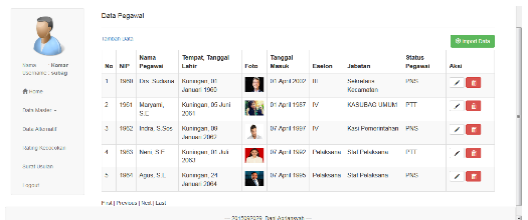

Gambar 7 Antarmuka Data Pegawai

Gambar 7 merupakan antarmuka Data Pegawai, antarmuka Data Pegawai diakses oleh Sub Bagian Umum untuk melakukan pengelolaan Data Pegawai.

2. Antarmuka Data Kuisioner

Antarmuka Data Kuisioner pada Sistem ditampilkan seteleh proses login oleh user (Sub Bagian Umum), sebagaimana terlihat pada Gambar 8.

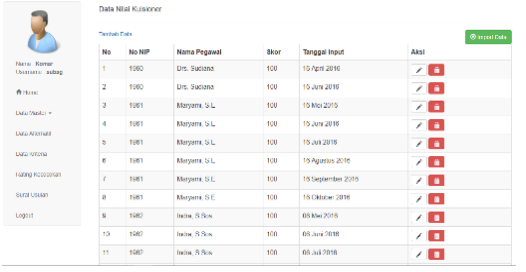

Gambar 8 Antarmuka Data Kuisioner

Gambar 8 merupakan antarmuka Data Kuisioner, antarmuka Data Kuisioner diakses oleh Sub Bagian Umum untuk melakukan pengelolaan Data Kuisioner.

3. Antarmuka Data Absensi

Antarmuka Data Absensi pada Sistem ditampilkan seteleh proses login oleh user (Sub Bagian Umum), sebagaimana terlihat pada Gambar 9.

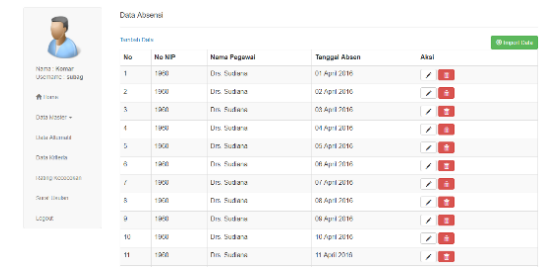

Gambar 9 Antarmuka Data Absensi 
Gambar 9 merupakan antarmuka Data Absensi, antarmuka Data Absensi diakses oleh Sub Bagian Umum untuk melakukan pengelolaan Data Absensi.

4. Antarmuka Daftar Alternatif

Antarmuka Daftar Alternatif pada Sistem ditampilkan seteleh proses login oleh user (Sub Bagian Umum), sebagaimana terlihat pada Gambar 10.

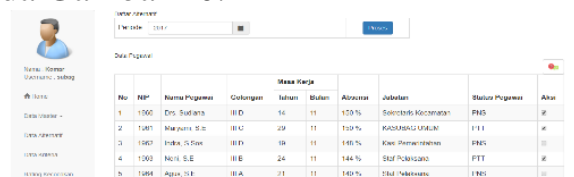

Gambar 10 Antarmuka Daftar Alternatif

Gambar 10 merupakan anatarmuka Daftar Alternatif, antarmuka Daftar Alternatif digunakan untuk menentukan Pegawai yang akan menjadi Alternatif untuk proses perhitungan dengan menggunakan model SAW.

5. Antarmuka Rating Kecocokan Antarmuka Rating Kecocokan pada Sistem ditampilkan seteleh proses login oleh user (Sub Bagian Umum), sebagaimana terlihat pada Gambar 11.

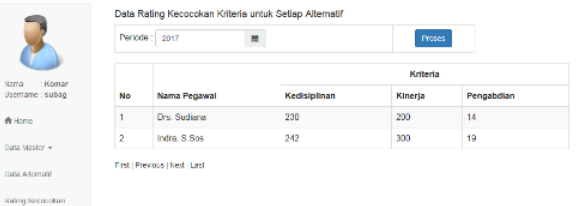

Gambar 11 Antarmuka Rating Kecocokan

Gambar 11 merupakan antarmuka Rating Kecocokan, antarmuka Rating Kecocokan adalah antarmuka yang memuat tentang data Rating Kecocokan Kriteria untuk Setiap Alternatif.

6. Antarmuka Data Surat Usulan

Antarmuka Data Surat Usulan pada Sistem ditampilkan seteleh proses login oleh user (Sub Bagian Umum), sebagaimana terlihat pada Gambar 12.

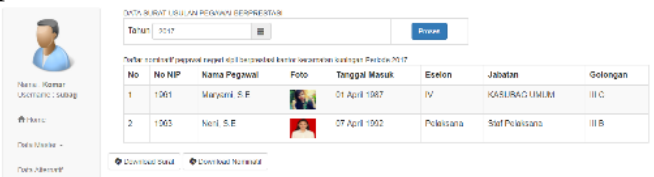

Gambar 12 Antarmuka Data Surat Usulan

Gambar 12 merupakan antarmuka Data Surat Usulan, antarmuka Data Surat Usulan adalah antarmuka yang memuat tentang Pegawai yang sudah di-acc untuk menerima usulan Pegawai Berprestasi, dan pada antarmuka ini terdapat fasilitas untuk mengunduh Surat Usulan dan Daftar Nominatif (lampiran Surat Usulan).

7. Antarmuka Laporan Calon Penerima Pegawai Berprestasi

Antarmuka Laporan Calon Penerima Pegawai Berprestasi pada Sistem ditampilkan seteleh proses login oleh user (Camat), sebagaimana terlihat pada Gambar 13.

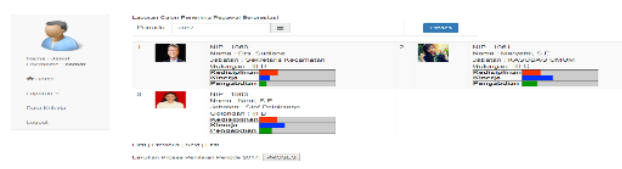

Gambar 13 Antarmuka Laporan Calon Penerima Pegawai Berprestasi

Gambar 13 merupakan antarmuka Laporan Calon Penerima Pegawai Berprestasi, antarmuka ini digunakan oleh Camat dalam melihat Laporan Calon Penerima Pegawai Berprestasi secara statistik. Pada antarmuka ini juga Camat dapat melakukan seleksi Pegawai Berprestasi menggunakan model SAW.

8. Antarmuka Laporan Hasil Seleksi Pegawai Berprestasi

Antarmuka Laporan Hasil Seleksi Pegawai Berprestasi pada Sistem ditampilkan seteleh proses login oleh user (Camat), sebagaimana terlihat pada Gambar 14.

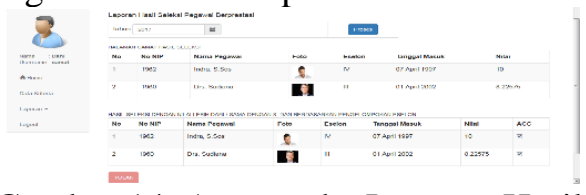

Gambar 14 Antarmuka Laporan Hasil Seleksi Pegawai Berprestasi

Gambar 14 merupakan antarmuka Laporan Hasil Seleksi Pegawai Berprestasi, antarmuka ini digunakan oleh Camat dalam melihat Laporan Hasil Seleksi Pegawai Berprestasi. Pada antarmuka ini juga Camat dapat melakukan evaluasi terhadap hasil seleksi Pegawai Berprestasi melalui fasilitas Acc atau Tolak. 
9. Antarmuka Laporan Daftar Nominatif Pegawai Berprestasi

Antarmuka Laporan Daftar Nominatif Pegawai Berprestasi pada Sistem ditampilkan seteleh proses login oleh user (Camat), sebagaimana terlihat pada Gambar 15.

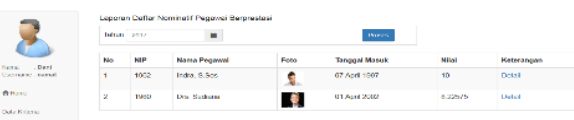

Gambar 15 Antarmuka Laporan Daftar Nominatif Pegawai Berprestasi

Gambar 15 merupakan antarmuka Laporan Daftar Nominatif Pegawai Berprestasi, antarmuka ini digunakan oleh Camat dalam melihat Laporan Daftar Nominatif Pegawai Berprestasi.

10. Antarmuka Laporan Daftar Surat Usulan Pegawai Berprestasi

Antarmuka Laporan Daftar Surat Usulan Pegawai Berprestasi pada Sistem ditampilkan seteleh proses login oleh user (Camat), sebagaimana terlihat pada Gambar 16.

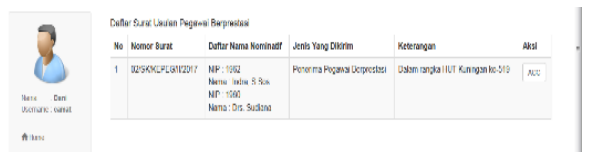

Gambar 16 Antarmuka Laporan Daftar Surat Usulan Pegawai Berprestasi

Gambar 16 merupakan antarmuka Laporan Daftar Surat Usulan Pegawai Berprestasi, antarmuka ini digunakan oleh Camat dalam melihat Laporan Daftar Surat Usulan Pegawai Berprestasi. Pada antarmuka ini juga Camat dapat melihat Surat Usulan dan melakukan acc terhadap Surat Usulan tersebut.

\section{KESIMPULAN}

1. Sistem yang dibangun dapat mendukung pimpinan (Camat) dalam pengambilan keputusan yang cepat, tepat sasaran dan objektif.

2. Metode SAW dapat diimplementasikan pada Sistem Pendukung Keputusan Seleksi Penerima Pegawai Berprestasi.
3. Sistem dapat diimplementasikan dengan teknik pendekatan pengembangan sistem terstruktur menggunakan bahasa pemrograman PHP dan DBMS MySQL.

\section{SARAN}

1. Diharapkan dapat menggunakan verifikasi secara otomatis pada proses verifikasi penentuan Pegawai menjadi Alternatif.

2. Diharapkan untuk penelitian selanjutnya dapat digunakan metode yang berbeda selain metode SAW.

3. Diharapkan pada penelitian selanjutnya ada penambahan fasilitas import data dengan ekstensi *.sql pada proses import data master. Selain itu, untuk antarmuka Sistem diharapkan dapat dikembangkan menjadi lebih responsif.

\section{REFERENSI}

Apriansyah, D. (2015). Aplikasi Sistem Inventory dengan Menggunakan Metode First-In First-Out FIFO. Tugas Akhir Pada FKOM UNIKU. Kuningan: Tidak Dipublikasikan.

ELCOM. (2010). Seri Belajar Kilat Adobe Dreamweaver CS5. Yogyakarta: Andi.

Fakultas Ilmu Komputer Universitas Kuningan. (2014). Pedoman Penyusunan Skripsi dan Tugas Akhir. Kuningan: FKOM UNIKU.

Febriyati, Merlien N. (2016). Perbandingan SAW Dan Topsis Untuk Open Recruitment Warga Laboratorium Teknik Informatika Di Universitas Trunojoyo Madura. Jurnal SimanteC [Online]. Vol 5(3), 10 Halaman. Tersedia: http://journal.trunojoyo.ac.id/simantec/ article/download/2348/2078 [14 Juni 2017]. 
Hartono, J. (2005). Analisis \& Desain Sistem Informasi: Pendekatan Terstruktur Teori dan Praktik Aplikasi Bisnis. Yogyakarta: Andi.

Kadir, A. (2009). Dasar Perancangan \& Implementasi Database Relasional. Yogyakarta: Andi.

Kusrini. (2007). Konsep dan Aplikasi Sistem Pendukung Keputusan. Yogyakarta: Andi.

Kusumadewi. (2006). Fuzzy Multi-Atrribute Decision Making (Fuzzy MADM). Yogyakarta: Graha Ilmu.

Ladjamuddin B, Al-Bahra. (2006). Rekayasa Perangkat Lunak. Yogyakarta: Graha Ilmu.

Nugroho, A. (2011). Perancangan dan Implementasi Sistem Basis Data. Yogyakarta: Andi.

Nugroho, B. (2013). Panduan Membuat Program Toko dengan Visual Basic dan $M y S Q L$. Yogyakarta: Gava Media.

Nurul-Janah, N.A.R. (2015). Aplikasi Sistem Pendukung Keputusan Penilaian DP3 Pada Sistem Informasi Sumber Daya Manusia Menggunakan Metode Perbandingan Eksponensial. Skripsi Pada FKOM UNIKU. Kuningan: Tidak Dipublikasikan.

Peraturan Bupati Kuningan. (2015). Pemberian Penghargaan Kepada Pegawai Negeri Sipil Berprestasi Di Lingkungan Pemerintah Kabupaten Kuningan. Kuningan: Badan Kepegawaian Daerah.

Prasetya, A. Hery. (2010). Cepat Kuasai PHP dan MySQL. Yogyakarta: Andi.

Pratama, F. San. (2016). Sistem Pendukung Keputusan Penerimaan Siswa Baru Menggunakan Metode SAW (Studi Kasus: SMK Ipiems Surabaya). Jurnal
Manajemen Informatika [Online]. Vol 5(2), 143-151 (9) halaman. Tersedia: http://jurnalmahasiswa.unesa.ac.id/artic le/20412/65/article.pdf [14 Juni 2017].

Pressman, R. S. (2012). Rekayasa Perangkat Lunak (Ed. 7). Yogyakarta: Andi.

Sidik, B. dan Husni. (2012). Pemrograman Web dengan HTML. Bandung: Informatika.

Sutaji, D. (2012). Sistem Inventory Mini Market dengan PHP \& Jquery. Yogyakarta: Lokomedia.

Wahana Komputer. (2010). PHP Source Code. Yogyakarta: Andi.

Wardiniyanti, M. (2013). Perancangan Aplikasi Perhitungan Harga Pokok Produksi dengan Menggunakan Metode JOB Order Costing di CV Eka Lingga Putra. Skripsi Pada FKOM UNIKU. Kuningan: Tidak Dipublikasikan.

Zimmermann. (1991). Fuzzy Sets Theory and Its Applications. Edisi 2. Kluwer Academic Publishers. Massachusetts. 